\title{
Pregnancy Diagnosis with Progesterone ELISA Kit in Farm Animals, Its Accuracy and Application
}

\author{
Sambriddhi Nepal ${ }^{1 *}$, Deepak Subedi ${ }^{1}$, Krishna Kaphle ${ }^{2}$ \\ ${ }^{1}$ Paklihawa Campus, Institute of Agriculture and Animal Science, Tribhuvan University, \\ Paklihawa, Siddharthanagar-1, Rupandehi, Nepal \\ ${ }^{2}$ Department of Theriogenology, Paklihawa Campus, Institute of Agriculture and Animal \\ Science, Tribhuvan University, Paklihawa, Siddharthanagar-1, Rupandehi, Nepal
}

\begin{abstract}
Pregnancy is a special condition where a female lodges one or more young ones within her uterus. It is maintained by various endocrine physiology and metabolic changes between maternal and fetal circumstances. Space dine secreted by corpus luteum increases extraordinarily throughout the pregnancy, estrogen increases rapidly during first trimester and prolonged lifespan of corpus luteum and small quantity of estrogen prevents prostaglandins pulsatic secretion. We reviewed available literature to evaluate the accuracy of progesterone ELISA test kit in pregnancy diagnosis in farm animals. We found varying accuracy in global and Nepalese context but found that this is an important tool for early pregnancy diagnosis and infertility monitoringwith high accuracy which contributes to increase economic efficiency of a farm. This kit has been used for qualitative and quantitative study of progesterone to understand the reproductive status of animals. Therefore, its use is increasing in globally and in Nepal. This kit has been used at various breeding centers, and livestock service centers of Nepal. However, wider level use is still difficult due to lack of infrastructuresand subsistence farming.
\end{abstract}

Keywords: ELISA Kit, Pregnancy diagnosis, Progesterone

\section{INTRODUCTION}

Pregnancy or gestation is the condition or time of a female while one or more young ones are developing within her uterus, maintained by various endocrines physiology and metabolic changes between mother and fetal boundary.Pregnancy diagnosis is a matter of curiosity for farmers since long time (Purohit, 2010). Early pregnancy diagnosis is associated with profitability of the farm due to factors like amount of milk or meat or fleece produced per day per herd, decisions of keeping or culling, feeding schedules and formulations (Dionysius, D.A.,1991) as well as the identification of reproductive diseases for their early treatment and rebreeding of the healthy non-pregnant ones (Engeland, Ropstad and Eik, 1997).

Per cow per day loss will be approximately US\$ 2 due to variable costs like feeding costs, breeding costs, labor costs, veterinary costs etc. (Ali, 2011); if the animal delays conception beyond 85 days postpartum which will increase the calving interval of the animal (Stevenson and Call, 1986). Pregnancy diagnosis is a key for shortening the calving interval by reducing the postpartum barren interval in farm animals (Balhara, Gupta, Singh, Mohanty, and Singh, 2013). So, the main target in a herd is not to allocate the pregnant but to identify the non pregnant animals and re-inseminating her as early as possible (Stevenson and Call, 1986) 
Animal farm management will be vague and economically boredom without early diagnosis of pregnancy in farm animals. Accurate and early gestation diagnosis is essential which helps in proper management and identification and rebreeding of the non pregnant at the earliest. An early pregnancy diagnosis is essential in mares to tease them if non pregnant, and try to get them pregnant in the same season (Sah et.al., 2017).

Progesterone (P4), an endogenous steroid is a progestogen sex hormone (Sah et.al., 2017). It targets the uterine epithelium, mammary tissue, myometrium and hypothalamus causing endometrial secretion, reducing cervical mucus production, inhibition of GnRH release and promotes maintenance of pregnancy. Its main source is corpus luteum or yellow body of ovary (Stevenson and Call, 1986). But, during pregnancy of farm animals, there is wide species variation in source of progesterone. In case of sow and goat, corpus luteum is very essential source throughout the pregnancy. In sheep and mare, placental production of progesterone in sufficient quantity starts in about 50 and 70 days of pregnancy respectively. P4 gets secreted into blood and subsequently into milk. But its level is higher in milk than in blood due to having more affinity of steroids towards milk fat.

Progesterone at low level stimulates ovulation by promoting release of LH in coordination with estrogen, while at high level of progesterone; it hinders the secretion of FSH and LH by negative feedback mechanism. But, FSH is released sufficiently so that follicles may progress in luteal phase. In a normally cycling cow, levels of $\mathrm{P} 4$ are relatively low in both blood and milk around estrus. Then P4 increases in both fluids. On day 17 or 18 of the estrous cycle, it declines as a new follicle develops. If a cow is pregnant, P4 levels would not decrease on day 17 or 18, but would remain elevated (Petersson, 2007).

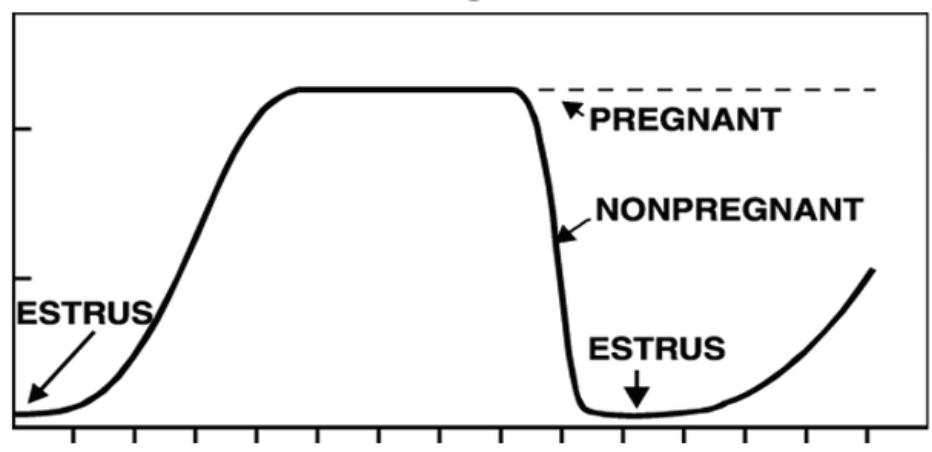

Figure 1. Changes in progesterone levels throughout the estrous cycle (adopted from Silvia and Heersche)

Progesterone quantification in blood and milk in laboratory can be obtained by Radioimmunoassay (RIA) or Enzyme-Linked Immuno-Sorbent Assay (ELISA) methods (Sah et al., 2017). This quantification could help in pregnancy examination as early as 21 days after natural or artificial insemination (Fricke et.al., 2016). This possibility that progesterone assay in plasma and milk could guide early pregnancy diagnosis in farm animals was proposed in 1971 by Laing and Heap (Rioux and Rajotte, 2004) 


\section{METHODS FOR PREGNANCY DIAGNOSIS}

The ideal pregnancy diagnosis methods should have high sensitivityto detect pregnant animals and high specificity to detect non-pregnant ones. In addition, they need to be convenient to be used in field conditions and inexpensive for farmers to adopt it. The additional qualities such as embryonic or fetal viability, sex determination for the future benefit would add value to it (Fricke et.al., 2016).

There are various direct and indirect methods for rapid and early gestation diagnosis in animals (Fricke et.al., 2016). Repeat heat in 18/24 days post insemination, rectal palpation to find uterus and its contents (expert clinician can detect as early as in 35 days ), ultrasonography and radioimmunoassay or enzyme linked assay of Progesterone hormone in blood serum, plasma and milk of lactating animals are some of them. There are mainly five chemical test kits available for detecting the hormone in milk and one for the blood serum in heifers (Stevenson and Call, 1986). And, the various ELISA kits available are Progesterone ELISA kit from the Abraxis LCC USA Company (used in A.K. Sahs' experiment), Ovucheck product no.C006 purchased from the North American distributor Biovet, Saint-Hyacinthe, QC, Canada (in Stevenson and Calls' experiment), Noctech Progesterone EIA (used in Dionysius' experiment), and Enzygnost Milk Progesterone Vet\$ (in Dionysius experiment).

Cattle has an estrous cycle of 21 days. Estrus duration is 18 hours on average and ovulation starts nearly 11 hours later. The size of corpus luteum increases significantly from day 3 to 12 and same does the level of progesterone in blood and milk (Rioux and Rajotte, 2004). Fluctuation in level of milk and blood progesterone implies the changes in the reproductive condition of farm animals (Romangolo and Nebel, 1993). These changes thus can monitor the manager to assess the optimal time of artificial insemination of the animals to obtain the better establishment of pregnancy. Significantly less than $10 \%$ of all herds are currently using milk progesterone as a diagnostic aid.

\section{SCENARIO OF PREGNANCY DIAGNOSIS IN LIVESTOCK IN NEPAL}

In the context of Nepal, farmers need to wait for more than a month to know the status of their cattle's pregnancy when cattle return to heat in about 21-22 days of estrous cycle. Only the trained and skilled expert can detect the pregnancy by rectal palpation in one month, the accuracy of which is highly variable (Sah et.al., 2017).Annual report of NCRP, 2016 have highlighted that early pregnancy diagnosis to maintain the reproductive efficiency offarmanimals have been a challenge in Nepal due to the lack of infrastructures such as the Ultrasonography (USG) machine, trained personnel to use it and poor economic status of farmers in rural areas (Sah et.al., 2017).

\section{RESULT}

We reviewed availablescientific articles to identify the accuracy of progesterone kit in Nepal for pregnancy diagnosis in differentfarm animals such as sheep, goat, cattle of various breeds. We found varying percentage for accuracy of progesterone kits ranging from 60 to 100\% for pregnant and 80 to $100 \%$ for non-pregnant with varying degree of sensitivity and specificity. In a 
research of Chitwan, Nepal, 80\% accuracy with 92\% sensitivity and 57\% specificity was found (Sah et.al., 2017). The results of progesterone kit in pregnancy diagnosis in different farm animals are presented in Table 1.

Table 1. Results of progesterone kit accuracy in the pregnancy diagnosis in different farm animals

\begin{tabular}{|c|c|c|c|c|c|c|c|c|}
\hline \multirow[t]{2}{*}{ SN } & \multirow[t]{2}{*}{ Farm animals } & \multirow{2}{*}{$\begin{array}{l}\text { Number of } \\
\text { animals }\end{array}$} & \multirow[t]{2}{*}{ Types of samples } & \multirow{2}{*}{$\begin{array}{l}\text { Days } \\
\text { sampling } \\
\text { (Post- } \\
\text { insemination) }\end{array}$} & \multicolumn{2}{|c|}{ Accuracy percentage } & \multirow[t]{2}{*}{ Remarks } & \multirow[t]{2}{*}{ Reference } \\
\hline & & & & & Positive & Negative & & \\
\hline 1 & $\begin{array}{l}\text { Crossbred Jersey } \\
\text { and Holstein dairy } \\
\text { cows }\end{array}$ & 20 & Blood (serum) & $37-40$ & 80 & & $\begin{array}{l}92 \% \text { sensitivity } \\
57 \% \text { specificity }\end{array}$ & Sah, et.al., 2017 \\
\hline \multirow[t]{2}{*}{2} & \multirow{2}{*}{$\begin{array}{l}\text { Lactating holstein } \\
+ \text { Guernsey cows }\end{array}$} & \multirow[t]{2}{*}{200} & Milk & $21-22$ & 77 & 100 & & \multirow[t]{2}{*}{ Zaied, et.al., 1979} \\
\hline & & & Milk & $27-28$ & 95 & 100 & & \\
\hline 3 & $\begin{array}{l}\text { Lactating Friesian } \\
\text { cow }\end{array}$ & 25 & $\begin{array}{l}\text { Blood (Periphe- } \\
\text { ral plasma) }\end{array}$ & $21-22$ & 85 & & & $\begin{array}{l}\text { (Skemesh, et.al., } \\
\text { 1973) }\end{array}$ \\
\hline \multirow[t]{2}{*}{4} & \multirow{2}{*}{$\begin{array}{l}\text { Lactating ewes of } \\
\text { local breed }\end{array}$} & \multirow[t]{2}{*}{62} & \multirow{2}{*}{$\begin{array}{l}\text { Blood (Periphe- } \\
\text { ral plasma) }\end{array}$} & 16-21 & 93 & \multirow[t]{2}{*}{100} & & \multirow{2}{*}{$\begin{array}{l}\text { (Skemesh, et.al., } \\
\text { 1973) }\end{array}$} \\
\hline & & & & $31-35$ & 100 & & & \\
\hline 5 & $\begin{array}{l}\text { Lactating } \\
\text { Holestein cows }\end{array}$ & 91 & Milk & 20 & 67.3 & 87.2 & & (Cox et.al., 2010) \\
\hline 6 & Cows & 476 & & $21-24$ & 88.6 & 93.9 & & $\begin{array}{l}\text { (Reimers et.al., } \\
\text { 2010) }\end{array}$ \\
\hline \multirow[t]{4}{*}{7} & \multirow[t]{2}{*}{ Zebu cattle } & \multirow[t]{2}{*}{64} & Milk & \multirow[t]{2}{*}{20} & 84 & \multirow[t]{4}{*}{100} & & \multirow{4}{*}{$\begin{array}{l}\text { Alam, and Ghosh, } \\
1994\end{array}$} \\
\hline & & & Plasma & & 84 & & & \\
\hline & & & Milk & \multirow[t]{2}{*}{24} & 90 & & & \\
\hline & & & & & 92 & & & \\
\hline \multirow[t]{2}{*}{8} & \multirow{2}{*}{$\begin{array}{lr}\begin{array}{l}\text { Holstein } \\
\text { cows }\end{array} & \text { Friesian } \\
\text { parous }+ \text { Heifers) }\end{array}$} & \multirow[t]{2}{*}{$10+8$} & \multirow[t]{2}{*}{ Blood (plasma) } & 22 & 71.4 & \multirow[t]{2}{*}{100} & & \multirow{2}{*}{$\begin{array}{l}\text { Muhammd, et.al., } \\
2000\end{array}$} \\
\hline & & & & 25 & 83.3 & & & \\
\hline 9 & $\begin{array}{ll}\text { Italian } & \text { Friesian } \\
\text { cows } & \\
\end{array}$ & 82 & & $19-23$ & 92.3 & 68.2 & & $\begin{array}{l}\text { Romangolo, and } \\
\text { Nebel, } 1992\end{array}$ \\
\hline 10 & Dairy goats & 73 & Milk+ Blood & 20 & 82 & 88 & & $\begin{array}{l}\text { Engeland, et.al., } \\
1996\end{array}$ \\
\hline 11 & $\begin{array}{l}3 \quad \text { commercial } \\
\text { dairy goats }\end{array}$ & 28 & Milk & $21-24$ & 96.4 & 100 & & Dionysius, 1991 \\
\hline 12 & $\begin{array}{l}\text { Cows of } 4 \\
\text { commercial dairies }\end{array}$ & 42 & Milk & 22 & 65.5 & 90.9 & $\begin{array}{l}\text { Ovuch-eck EIA } \\
\text { was used }\end{array}$ & \\
\hline & & & & & 68.2 & 90 & $\begin{array}{l}\text { Enzygn-ost vet } \\
\text { was used }\end{array}$ & \\
\hline 13 & Dairy cattle & & Milk & $21-24$ & 84 & $90-100$ & & $\begin{array}{l}\text { Stevenson and } \\
\text { Call }\end{array}$ \\
\hline 14 & $\begin{array}{l}\text { Cows of } 14 \text { dairy } \\
\text { farms }\end{array}$ & 752 & Milk & & & & $\begin{array}{l}\text { 97\% heat } \\
\text { detection } \\
\text { accuracy; } 90 \% \\
\text { sensitivity } \\
98.7 \% \\
\text { specificity }\end{array}$ & $\begin{array}{l}\text { Ingenhoff, et.al., } \\
2013\end{array}$ \\
\hline 15 & Zebu cattles & 46 & Plasma & 20 & 84 & 100 & RIA was used & Alamand Ghosh, \\
\hline & & & & 24 & 90 & & $\begin{array}{lll}\text { with } & 125 & \text { I }\end{array}$ & 1994 \\
\hline & & 58 & Milk & 20 & 84 & & isotope. & \\
\hline & & & & 24 & 92 & & & \\
\hline
\end{tabular}

\section{DISCUSSION}

The ELISA kit has not gained popularity due to its low specificity and less accuracy. Progesterone kits are not used in NLBC, Pokhara and NCRP, Rampur, Chitwan currently for pregnancy diagnosis. Ultrasonography is the gold standard test for pregnancy diagnosis in Nepal (Personal communication Dr. A.K Sah). Various pregnancy specific proteins kits like BIOPRYN, with 100\% accuracy, have also been used for rapid test (Karki et.al., 2018). Even in 
IAAS farm, no provision of early pregnancy diagnosis is practiced using USG or progesterone assays. Rectal palpation only after 3 months is being practised, which is surely to increase the farm cost if the animal is detected to be open cow.

Accuracy of pregnancy positive is repeatedly lower than that of negative (non- pregnant), mostly due to various causes like embryonic mortality, inaccurate sampling, ovarian luteal cysts, prolonged luteal lifespan and breeding during luteal phase. Presence of some animals having long estrus intervals, or short estrous cycles increases the false positive results of this test. Cost of P4 testing and the labor involved in obtaining multiple samples also incur loss. Early pregnancy loss will also limit the accuracy of many direct and indirect methods of pregnancy diagnosis.

Potential uses of progesterone testing in a reproductive management program according to Nebel, R.L. are in identifying errors in detection of estrus. Animals with questionable signs of estrus can be verified by on-farm milk progesterone tests. Low P4 concentration of milk alone cannot be a single positive indicator of estrus. But, high P4 level confirms the non-estrus state of animals, even if they have any behavioral heat symptoms. Likewise, it may used to predict time of estrus. Level of progesterone will be very low at estrus and then will go increasing. If the animal gets fertilized, the level will remain elevated throughout the gestation but if not, it will be reduced rapidly in 17/18 days of estrous cycle (2-4 days before estrus) due to the decrease in the size of the corpus luteum in the absence of fertilization and again will come in heat. Likewise, the possibility of establishing a rapid gestation diagnosis in domestic animals by means of a progesterone assay in plasma and milk was introduced from 1971 by Laing and Heap (Rioux and Rajotte, 2004). This is also helpful in differentiating types of ovarian cysts. Ovarian cysts mainly follicular and luteal cysts can be differentiated by the quantification of progesterone where follicular cyst is characterized by low progesterone level whereas luteal cyst is characterized by very high level of progesterone, sometimes up to $\mathrm{ml}$ in milk or blood. In addition, this test has been used in evaluating response to endocrine therapy. Any endocrine treatment affecting the ovarian status can be evaluated by the progesterone test. Example: for follicular cyst for leutinization, if GnRH is administered, Progesterone testing 10 days after $\mathrm{GnRH}$ administration could guide accurately if retreatment is needed or not.

\section{CONCLUSION AND RECOMMENDATION}

Progesterone (P4) is very crucial component of pregnancy and uterine biology, as well as for mammogenesis and lactogenesis. Due to having less accuracy and specificity, progesterone ELISA cannot be used for confirmatory diagnosis, but can be used for screening purpose after 21 days post insemination. In agro-veterinary sciences, one can demonstrate the usefulness and efficiency of this test to predict estrus (heat), gestation, and to evaluate pathological conditions and responses to different hormone-based medicines. However, further research is needed to determine the relative milk progesterone concentrations to improve the reproductive efficiency and economy of dairy farms.

We recommend that due to less accuracy and specificity of progesterone assay, it should not be used for confirmatory pregnancy but may be used as a part of the reproductive management program. 


\section{ACKNOWLEDGEMENT}

We would like to express our sincere gratitude and deep appreciation for the continued guidance and encouragement throughout the process of reviewing and writing articles towards Dr. Anjay Kumar Sah, Dr. Bhaju Mahato, Sujata Acharya, Shrinu Jha, Pratiksha Parajuli and all other helping hands.

\section{REFERENCES}

Alam, M. G. S., and Ghosh, A. (1994). Plasma and milk progesterone concentrations and early pregnancy in Zebu cows. Asian-Australasian Journal of Animal Sciences, 7 (1), 131-136.

Ali, S. (2011). Economic Losses Due to Delayed Conception in Dairy Animals of Small Farmers in District Gujranwala. 75. Retrieved from http://icdd.uaf.edu.pk/Publications/011.pdf

Balhara, A. K., Gupta, M., Singh, S., Mohanty, A. K., and Singh, I. (2013). Early pregnancy diagnosis in bovines: Current status and future directions. The Scientific World Journal, 2013. https://doi.org/101155/2013/958540

Cox, N. M., Thompson, F. N., and Culver, D. H. (2010). Milk Progesterone to Predict Reproductive Status in a Commercial Dairy Herd. Journal of Dairy Science, 61 (11), 16161621. https://doi.org/10.3168/jds.s0022-0302 (78)83773-4

Dionysius, D. A. (1991). Pregnancy diagnosis in dairy goats and cows using progesterone assay kits Aust Vet J., 68 (1):14-6. DOI:10.1111/j.1751-0813.1991.tb09832.x

Engeland, I. V., Ropstad, E., Andresen, Ø., andEik, L. O. (1997). Pregnancy diagnosis in dairy goats using progesterone assay kits and oestrous observation. Animal reproduction science, 47 (3), 237-243.

Fricke, P. M., Ricci, A., Giordano, J. O., and Carvalho, P. D. (2016). Methods for and Implementation of Pregnancy Diagnosis in Dairy Cows. Veterinary Clinics of North America - $\quad$ Food Animal Practice, 32 (1), 165-180. https://doi.org/10.1016/j.cvfa.2015.09.006

Hirpa, A., Yehualaw, B., Wube, A., Asnake, A., Jemberu, A., Medicine, V., and Box, P. O. (2018). Review on Pregnancy Diagnosis in Dairy Cows. 9 (2), 45-55. https://doi.org/10.5829/idosi.jri.2018.45.55

Ingenhoff, L., Hall, E., and House, J. K. (2016). Evaluation of a cow-side milk progesterone assay and assessment of the positive predictive value of oestrus diagnosis by dairy farmers in New South Wales. Australian Veterinary Journal, 94 (12), 445-451. https://doi.org/10.1111/avj.12532

Karki, B., Raut, R., Sankhi, K. P., Mandal, U., and Gautam, G. (2018). Fertility Improvement by Ovsynch Protocol in Repeat Breeder Cattle of Kathmandu Valley. International Journal of Applied Sciences and Biotechnology, 6 (3), 261-264.

https://doi.org/10.3126/ijasbt.v6i3.21183

Lab Tests Online. (2019). Dehydroepiandrosterone | You and Your Hormones from the Society for Endocrinology. Retrieved from http:/www.yourhormones.info/hormones/dehydroepiandrosterone/

Muhammad F, Sarwar A., Hayat C. S., A. M. I. (2000). Peripheral Plasma Progesteron Concentration During Early Pregnancy in Holstein Feiesian Cows. Pakistan Veterinary Journal, Vol. 20, pp. 166-168.

Nebel, R. L. (1988). On-Farm Milk Progesterone Tests. Journal of Dairy Science, 71 (6), 16821690. https://doi.org/10.3168/jds.s0022-0302 (88)79733-7 
Petersson, K. J. (2007). Milk progesterone as a tool to improve fertility in dairy cows (Vol. 2007, No. 46).

Purohit, G. (2010). Methods of Pregnancy Diagnosis in Domestic Animals: The Current Status Animals: The Current Status. WebmedCentral REPRODUCTION, 1 (12):WMC001305

Reimers, T. J., Smith, R. D., and Newman, S. K. (1985). Management factors affecting reproductive performance of dairy cows in the northeastern United States. Journal of Dairy Science, 68 (4), 963-972. https://doi.org/10.3168/jds.s0022-0302 (85)80916-4

Rioux, P., and Rajotte, D. (2004). Progesterone in milk: a simple experiment illustrating the estrous cycle and enzyme immunoassay. Advances in Physiology Education, 28 (2), 6467. https://doi.org/10.1152/advan.00048.2002

Romagnolo, D., andNebel, R. L. (1993). The accuracy of enzyme-linked immunosorbent assay and latex agglutination progesterone test for the validation of estrus and early pregnancy diagnosis in dairy cattle. Theriogenology, 39 (5), 1121-1128.

Sah, A. K., Bastola, R., Pandeya, Y. R., Pathak, L., Acharya, M. P., and Khanal, D. R. (2017). Accuracy of Pregnancy Diagnosis with Commercially Available Progesterone Kit in Dairy Cows. Nepalese Veterinary Journal, 34, 101-106. https://doi.org/10.3126/nvj.v34i0.22908

Skemesh, M., Ayalon, N., and Lindner, H. R. (1973). Early pregnancy diagnosis based upon plasma progesterone levels in the cow and ewe. Journal of animal science, 36 (4), 726-729.

Stevenson, J. S., and Call, E. P. (1986). Milk progesterone kits: On-farm use. Kansas Agricultural Experiment Station Research Reports, (2), 81-82. https://doi.org/10.4148/2378-5977.3074

Zaied, A. A., Bierschwal, C. J., Elmore, R. G., Youngquist, R. S., Sharp, A. J., andGarverick, H. A. (1979). Concentrations of progesterone in milk as a monitor of early pregnancy diagnosis in dairy cows. Theriogenology, 12 (1), 3-11. 